\title{
Transmitter Device
}

National Cancer Institute

\section{Source}

National Cancer Institute. Transmitter Device. NCI Thesaurus. Code C50231.

A device to propagate electromagnetic waves. 